Original Article

\title{
Bioinformatics and expression analysis of the Xeroderma Pigmentosum complementation group C (XPC) of Trypanosoma evansi in Trypanosoma cruzi cells
}

\author{
Análises de bioinformática e da expressão do gene Xeroderma Pigmentosum \\ complementation group C (XPC) de Trypanosoma evansi em células de Trypanosoma cruzi
}

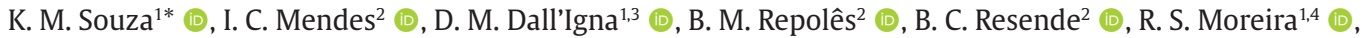 \\ L. C. Miletti ${ }^{1}$ (D) C. R. Machado ${ }^{2}$ (D) and C. I. G. Vogel ${ }^{1}$ (D) \\ ${ }^{1}$ Universidade do Estado de Santa Catarina, Departamento de Produção Animal e Alimentos, Lages, SC, Brasil \\ ${ }^{2}$ Universidade Federal de Minas Gerais, Instituto de Ciências Biológicas, Departamento de Bioquímica e Imunologia, Belo Horizonte, MG, Brasil \\ ${ }^{3}$ Universidade do Planalto Catarinense, Lages, SC, Brasil \\ ${ }^{4}$ Instituto Federal de Santa Catarina, Departamento de Ensino, Pesquisa e Extensão, Lages, SC, Brasil
}

\begin{abstract}
Nucleotide excision repair (NER) acts repairing damages in DNA, such as lesions caused by cisplatin. Xeroderma Pigmentosum complementation group C (XPC) protein is involved in recognition of global genome DNA damages during NER (GG-NER) and it has been studied in different organisms due to its importance in other cellular processes. In this work, we studied NER proteins in Trypanosoma cruzi and Trypanosoma evansi, parasites of humans and animals respectively. We performed three-dimensional models of XPC proteins from T. cruzi and $T$. evansi and observed few structural differences between these proteins. In our tests, insertion of XPC gene from T. evansi (TevXPC) in T. cruzi resulted in slower cell growth under normal conditions. After cisplatin treatment, $T$. cruzi overexpressing its own XPC gene (TCXPC) was able to recover cell division rates faster than T. cruzi expressing TevXPC gene. Based on these tests, it is suggested that TevXPC (being an exogenous protein in T. cruzi) interferes negatively in cellular processes where TcXPC (the endogenous protein) is involved. This probably occurred due interaction of TevXPC with some endogenous molecules or proteins from T.cruzi but incapacity of interaction with others. This reinforces the importance of correctly XPC functioning within the cell.
\end{abstract}

Keywords: Nucleotide excision repair (NER), Xeroderma Pigmentosum complementation group C (XPC), T. evansi, T. cruzi.

\begin{abstract}
Resumo
O reparo por excisão de nucleotídeos (NER) atua reparando danos no DNA, como lesões causadas por cisplatina. A proteína Xeroderma Pigmentosum complementation group C (XPC) está envolvida no reconhecimento de danos pela via de reparação global do genoma pelo NER (GG-NER) e tem sido estudada em diferentes organismos devido à sua importância em outros processos celulares. Neste trabalho, estudamos proteínas do NER em Trypanosoma cruzi e Trypanosoma evansi, parasitos de humanos e animais, respectivamente. Modelos tridimensionais das proteínas XPC de T. cruzi e T. evansi foram feitos e observou-se poucas diferenças estruturais entre estas proteínas. Durante testes, a inserção do gene XPC de T. evansi (TevXPC) em T. cruzi resultou em crescimento celular mais lento em condições normais. Após o tratamento com cisplatina, T. cruzi superexpressando seu próprio gene XPC (TcXPC) foi capaz de recuperar as taxas de divisão celular mais rapidamente do que T. cruzi expressando o gene TevXPC. Com base nesses testes, sugere-se que TevXPC (sendo uma proteína exógena em T. cruzi) interfere negativamente nos processos celulares em que TcXPC (a proteína endógena) está envolvida. Isso provavelmente ocorreu pois TevXPC é capaz de interagir com algumas moléculas ou proteínas endógenas de T.cruzi, mas é incapaz de interagir com outras. Isso reforça a importância do correto funcionamento de XPC dentro da célula.
\end{abstract}

Palavras-chave: Reparo por excisão de nucleotídeos (NER), Xeroderma Pigmentosum complementation group C (XPC), T. evansi, T. cruzi.

*e-mail: ketriane@hotmail.com

Received: October 1, 2020 - Accepted: Março 23, 2021

This is an Open Access article distributed under the terms of the Creative Commons Attribution License, which permits unrestricted use, distribution, and reproduction in any medium, provided the original work is properly cited. 


\section{Introduction}

Trypanosoma cruzi is the causative agent of Chagas disease or American trypanosomiasis, which infects about six to seven million people worldwide, mostly in Latin America (WHO, 2020; Bianchi et al., 2021), considered a typical disease of low-income population developing countries (Dutra et al., 2021). In fact, vectorborne transmission is limited to areas of South, Central and North Americas (Bern, 2015). Its transmission occurs mainly by blood-sucking reduviid insects through metacyclic trypomastigotes releasement in the feces during the insect blood meal and the entry of these parasites in mammalian host through skin wounds or mucosal membranes (Moretti et al., 2020).

Trypanosoma evansi is the causative agent of "Surra" disease. Despite this disease was endemic in the 1990s in China, affecting animals like buffaloes, cattle, camels and dogs, there are few epidemiological studies conducted on this subject in the past decade (Zheng et al., 2019). "Surra" presents non-specific clinical signs such as weight loss, anorexia, anemia, drop in milk production and reproductive disorders, impacting on economic business (Setiawan et al., 2021). Although this parasite can affect most of the mammals, human infection is rare (Desquesnes et al., 2013; Wabale et al., 2015). The mechanical transmission by biting insects represents the most important way of T. evansi transmission (Desquesnes et al., 2013). In Brazil, some studies emphasize that $T$. evansi is spreading, with new cases arising in regions previously free of infection, sustaining the need for precise measures of active surveillance for "Surra" (Reck et al., 2020).

Expanding knowledge about trypanosomatids biology is a way to better elaborate strategies for diseases control. An important study is the investigation of how these parasites maintain the integrity of their DNA. According to Sancar et al., (2004), DNA lesions in organisms can result in mutation, cancer, cell death or even organism failure. Nucleotide excision repair (NER) eliminates DNA lesions capable of causing double helix distortion, base pairing interference as well as blocking of transcription and replication (Costa et al., 2003). An example of an agent that causes DNA damage repaired by NER is cisplatin (Kang et al., 2010). Since cisplatin is a DNA-damaging agent and unrepaired DNA would lead to cell death, the ability of a cell to survive when exposed to this drug could depend on the efficiency of its DNA-repair mechanisms (Masters and Köberle, 2003).

NER system has two sub-pathways: (1) Global genome nucleotide excision repair (GG-NER) which recognizes damage from both expressed or silent parts of the genome and (2) Transcription-coupled NER (TC-NER), which recognizes damages that interfere in the elongation of RNA polymerase (Hanawalt and Spivak, 2008). Xeroderma Pigmentosum complementation group $\mathrm{C}(\mathrm{XPC})$ protein acts on the recognition process of ultraviolet (UV) DNA lesions and other bulky DNA adducts on the GG-NER, dependent of XPA, RPA and Transcription Factor II-H (TFIIH) proteins at the damage site, where the latter unwinds the double helix of DNA around the lesions (Kemp and Hu, 2017). Subsequently, XPG and XPF/ERCC1 are recruited to remove the damaged fragment (Staresincic et al., 2009). A new DNA strand is synthesized at the site of the incision and ligated to the DNA duplex (Kemp and Hu, 2017). In TC-NER, the initial lesion recognition is made through the stalled RNA Pol at lesions during transcription, and this increases the polymerase interaction with Cockayne syndrome type B (CSB) protein (Vessoni et al., 2020). Thus, RNA Pol translocation along the DNA strand is stimulated and the TFIIH complex accesses the lesion site (Hanawalt and Spivak, 2008). The next steps are similar for TC-NER and GG-NER (Schärer, 2013).

Regarding NER in trypanosomatids, the genomes of $T$. cruzi, Trypanosoma brucei and Leishmania major contain the majority of the NER components, but the biochemical mechanisms of this pathway may present some minor differences as compared to more complex eukaryotes (Passos-Silva et al., 2010). In T. brucei it has been shown that XPC gene silencing by RNA interference (RNAi) resulted in cell death, suggesting a vital role of this gene in T. brucei (Machado et al., 2014). Studies about NER genes and proteins from parasites contribute to the development of disease control strategies by understanding how these microorganisms deal with adversities that damage their DNA. In view of this, the goals of this work were to perform bioinformatic analysis in NER proteins from some trypanosomatids and evaluate the expression effects of XPC from T. evansi (TevXPC) in T. cruzi.

\section{Material and Methods}

\subsection{Bioinformatics analysis}

Gene ID's of trypanosomatids NER proteins studied in this work are presented in Table 1 which was adapted from Genois et al. (2014). Sequences of NER proteins were selected from TriTrypDB (Aslett et al., 2010) and NCBI (NCBI Resource Coordinators, 2018) databases. Proteins from $T$. evansi were aligned with their orthologues in $T$. brucei, T. cruzi, Leishmania major, Saccharomyces cerevisiae, and humans through Protein Blast from NCBI. Alignment between TcXPC and TevXPC was also performed using a tool that can align virtually protein sequences called Clustal Omega (Sievers et al., 2011). Protein domains were located using InterPro (Blum et al., 2021), which contains integrated databases as Pfam (Mistry et al. 2021), PROSITE (Hulo et al., 2006) and SMART (Letunic et al., 2021). Alignments of NER proteins domains in T. cruzi and $T$. evansi were performed through NCBI Protein Blast. Motifs in proteins were investigated through ScanProsite, a tool for detecting PROSITE signature matches in protein sequences (de Castro et al., 2006). Three-dimensional models of proteins were performed by Phyre2, a bioinformatic tool for prediction and analysis of protein structure, function, and mutations (Kelley et al., 2015). The amino acid sequences found in TriTrypDB were placed into Phyre2 and the "normal modelling mode" was chosen for generation of threedimensional models. This tool predicted TcXPC, TevXPC, and TbXPC protein's structure based on a crystal structure of Rad4-Rad23 bound to a mismatched DNA performed by Min and Pavletich (2007) and available in RCSB Protein 
Table 1. Trypanosomatids genes involved in nucleotide excision repair (NER). The ellipsis indicates that there are not homologs found (...). Adapted from Genois et al. (2014).

\begin{tabular}{|c|c|c|c|c|c|c|}
\hline & & & Gene ID & & & \\
\hline $\begin{array}{c}\text { Name } \\
\text { (other name) }\end{array}$ & T. evansi & T.brucei & T.cruzi & L. major & S. cerevisiae & Human \\
\hline XPA & $\ldots$ & $\ldots$ & $\ldots$ & $\ldots$ & YMR201C & NM_000380 \\
\hline XPC & TevSTIB805.9.8560 & Tb927.9.11930 & TcCLB.507011.140 & LmjF.35.3450 & YER162C & NM_004628 \\
\hline RAD23 & TevSTIB805.6.4810 & Tb927.6.4650 & TcCLB.511731.10 & LmjF.30.3300 & YEL037C & NM_005053 \\
\hline TFIIH-XPB & TevSTIB805.3.5380 & Tb927.3.5100 & TcCLB.510149.50 & LmjF.29.0590 & YIL143C & NM_000122 \\
\hline XPB-R & TevSTIB805.11_01.16840 & Tb927.11.16270 & TcCLB.511527.20 & LmjF.32.3920 & $\ldots$ & $\ldots$ \\
\hline TFIIH-XPD & TevSTIB805.8.6240 & Tb927.8.5980 & TCCLB.511075.30 & LmjF.24.2280 & YER171W & NM_000400 \\
\hline $\begin{array}{l}\text { TFIIH-Tfb1 } \\
\quad(\mathrm{p} 62)\end{array}$ & TevSTIB805.11_01.9710 & Tb927.11.9430 & TcCLB.511589.29 & LmjF.36.3110 & YDR311W & NM_005316 \\
\hline $\begin{array}{l}\text { TFIIH-Tfb2 } \\
\quad(\mathrm{p} 52)\end{array}$ & TevSTIB805.10.5510 & Tb927.10.5210 & TCCLB.510297.80 & LmjF.36.0800 & YPL122C & NM_001517 \\
\hline $\begin{array}{l}\text { TFIIH-Ssl1 } \\
\quad(\mathrm{p} 44)\end{array}$ & TevSTIB805.8.6840 & Tb927.8.6540 & TcCLB.511907.300 & LmjF.24.1680 & YLR005W & NM_001515 \\
\hline TFIIH-TSP1 & TevSTIB805.1.1030 & Tb927.1.1080 & TcCLB. 511423.40 & LmjF.20.0400 & $\ldots$ & $\ldots$ \\
\hline TFIIH-TSP2 & TevSTIB805.11_01.14590 & Tb927.11.14110 & TcCLB.511727.150 & LmjF.32.0860 & $\ldots$ & $\ldots$ \\
\hline $\begin{array}{l}\text { TFIIH-Tfb4 } \\
\quad(\mathrm{p} 34)\end{array}$ & TevSTIB805.11_01.16620 & Tb927.11.16070 & TcCLB.509073.60 & LmjF.32.2885 & YPR056W & NM_001516 \\
\hline TFIIH-Tfb5 & TevSTIB805.10.14950 & Tb927.10.14210 & TcCLB.511283.50 & LmjF.16.1145 & $\ldots$ & $\ldots$ \\
\hline XPG & TevSTIB805.9.8390 & Tb927.9.11760 & TcCLB.507009.120 & LmjF.35.3590 & YGR258C & NM_000123 \\
\hline ERCC1 & TevSTIB805.7.2130 & Tb927.7.2060 & TCCLB.510165.20 & LmjF.22.0070 & YML095C & NM_001983 \\
\hline $\mathrm{XPF}$ & TevSTIB805.5.4190 & Tb927.5.3670 & TcCLB.509779.10 & LmjF.08.0140 & YPL022W & NM_005236 \\
\hline RPA1 & TevSTIB805.11_01.9370 & Tb927.11.9130 & TCCLB.510901.60 & LmjF.28.1820 & YAR007C & NM_002945 \\
\hline RPA2 & TevSTIB805.5.1910 & Tb927.5.1700 & TCCLB.510821.50 & LmjF.15.0270 & YNL312W & NM_002946 \\
\hline RPA3 & $\ldots$ & $\ldots$ & $\ldots$ & $\ldots$ & YJL173C & NM_002947 \\
\hline Pol $\varepsilon$ & TevSTIB805.9.7440 & Tb927.9.10440 & TcCLB.506147.180 & LmjF.35.4360 & YNL262W & NM_006231 \\
\hline $\operatorname{Pol} \delta$ & TevSTIB805.2.970 & Tb927.2.1800 & TcCLB.510259.6 & LmjF.33.1690 & YDL102W & NM_002691 \\
\hline DNA ligase I & TevSTIB805.6.4950 & Tb927.6.4780 & TcCLB.506945.80 & LmjF.30.3440 & YDL164C & NM_000234 \\
\hline DDB1 & TevSTIB805.6.5280 & Tb927.6.5110 & TcCLB.509165.49 & LmjF.30.3710 & $\cdots$ & NM_001923 \\
\hline DDB2 & $\ldots$ & $\cdots$ & $\ldots$ & $\ldots$ & YDL156W & NM_000107 \\
\hline CSA & $\ldots$ & $\ldots$ & $\ldots$ & $\ldots$ & YDR030C & NM_000082 \\
\hline CSB & TevSTIB805.7.4360 & Tb927.7.4080 & TcCLB.508675.20 & LmjF.14.0840 & YJR035W & NM_000124 \\
\hline Def1 & $\ldots$ & $\ldots$ & $\ldots$ & $\ldots$ & YKL054C & NM_004084 \\
\hline HuF2 & TevSTIB805.11_01.8320 & Tb927.11.8010 & TcCLB.504041.29 & LmjF.28.0760 & YBR114W & NM_003594 \\
\hline
\end{tabular}

Data Bank (Berman et al., 2000). This crystal structure can be accessed through the PDB ID: 2QSH. The TcXPB, TevXPB, TcXPB-R and TevXPB-R proteins structures were performed based on a cryogenic electron microscopy structure of the human TFIIH core complex performed by Greber et al. (2019). This structure can be accessed through the PDB ID: 6NMI. All three-dimensional models generated were visualized and color edited through the PyMOL (www. pymol.org). The size space between parts of the protein models were measured through Jmol bioinformatic tool (jmol.sourceforge.net).

\subsection{In vivo culture of T. evansi and DNA extraction}

This work was approved by the Comitê de Ética em Experimentação Animal (Committee of Ethics in Animal Experimentation; CETEA) of the Santa Catarina State University (UDESC) under protocol number 2014 1.28.11. For parasite multiplication, one rat (Rattus norvegicus) was intraperitoneally infected with T. evansi cells (donated by Dr. Silvia Gonzalez Monteiro, UFSM, Rio Grande do Sul). Parasitemia was estimated by microscopic examination of tail blood smears stained with Panótico Rápido ${ }^{\circledR}$ (Laborclin, Solabia Group, Brazil). When 40 parasites/field in optical 
$100 \mathrm{x}$ was reached, the rat was anesthetized with xylazine (13 $\mathrm{mg} / \mathrm{kg}$ ) and ketamine ( $90 \mathrm{mg} / \mathrm{kg}$ ). The blood containing the parasites was collected by cardiac puncture and first it was separated by Percoll ${ }^{\circledR}$ (GE Healthcare, Illinois, USA) gradient (17,500xg, $\left.25 \mathrm{~min}, 4^{\circ} \mathrm{C}\right)$, (Grab and Bwayo, 1982). The supernatant obtained was washed twice with PBS with $2 \%$ glucose (PBS-G) $\left(6,000 x g, 10 \mathrm{~min}, 4{ }^{\circ} \mathrm{C}\right)$. After this, DEAE-cellulose (Sigma-Aldrich, Missouri, USA) chromatography was performed in a $10 \mathrm{~mL}$ syringe to the isolation of the parasites from blood cells (Lanham and Godfrey, 1970). Genomic DNA was extracted using the "Quick-DNA Universal Kit" (Zymo Research, California, USA) following the manufacturer's instructions.

\subsection{TevXPC coding region amplification}

The coding region of the TevXPC gene was amplified by Polymerase Chain Reaction (PCR) (Mullis et al., 1986). For this, the TevXPC gene sequence was found in TriTrypDB and we designed the following primers: TevXPC Fwd HindIII (5'- CCAAGCTTATGGGGCAGCAGAAAAAA -3') and TevXPC Rev Xhol (5' - CCCTCGAGTCAGTGAGAGGAAAGATG -3'). To amplify a 2307-bp fragment of TevXPC, the PCR was performed in accordance with the instructions from Q5 ${ }^{\circledR}$ High-Fidelity DNA-Polymerase manufacturer (New England Biolabs ${ }^{\circledR}$ Inc., Massachusetts, USA). The reaction mixture contained Q5 Reaction Buffer and Q5 High GC Enhancer at $1 \mathrm{X}$ final concentration, $1 \mathrm{U}$ Q $5^{\circledR}$ HighFidelity DNA Polimerase, $0.5 \mu \mathrm{M}$ of each primer, $200 \mu \mathrm{M}$ deoxynucleotide triphosphates (dNTPs), $111 \mathrm{ng}$ of T. evansi DNA and nuclease-free water to make up the final volume of $50 \mu \mathrm{L}$. The temperature conditions included initial denaturation at $98^{\circ} \mathrm{C}$ for 30 seconds, 32 cycles of $98^{\circ} \mathrm{C}$ for 10 seconds, $64^{\circ} \mathrm{C}$ for 30 seconds, and $72^{\circ} \mathrm{C}$ for 90 seconds, followed by 2 minutes at $72^{\circ} \mathrm{C}$. Amplicons were stained with GelRed ${ }^{\circledR}$ Nucleic Acid Gel Stain (Biotium, Inc., California, USA), analyzed through $1.5 \%$ gel agarose electrophoresis, and visualized under UV light in a gel documentation system (MiniBIS Pro (DNR Bio Imaging System, Neve Yamin, Israel)). To determine molecular weight, was used $1 \mathrm{~Kb}$ DNA Ladder (Invitrogen ${ }^{\mathrm{TM}}$, Massachusetts, USA).

\subsection{Gene cloning into $p G E M^{\circledR}-T$ Easy vector}

Amplicons were purified with PureLink Quick Gel Extraction Kit (Invitrogen ${ }^{\mathrm{TM}}$, Massachusetts, USA) and were A-tailed. The A-tailing reaction was conducted in a final volume of $10 \mu \mathrm{L}$ containing reaction buffer at $1 \mathrm{X}$ final concentration, $2.5 \mathrm{mM}$ magnesium chloride, $0.2 \mathrm{mM}$ deoxyadenosine triphosphate(dATP), 5 U Hot Start Platinum ${ }^{\mathrm{TM}}$ Taq DNA Polymerase (Invitrogen ${ }^{\mathrm{TM}}$, Massachusetts, USA) and $6.5 \mu \mathrm{L}$ of purified PCR fragment. The reaction mixture was incubated at $94^{\circ} \mathrm{C}$ for 2 minutes and 30 seconds, $60^{\circ} \mathrm{C}$ for 30 seconds and $72^{\circ} \mathrm{C}$ for 30 minutes. Amplicon A-tailed was inserted into the $\mathrm{pGEM}^{\circledR}$-T Easy vector (Promega ${ }^{\mathrm{TM}}$, Madison, USA) following the manufacturer's instructions. The ligation reaction was incubated at $4^{\circ} \mathrm{C}$ overnight and $5 \mu \mathrm{L}$ of this mixture was inserted into Escherichia coli DH10B electrocompetent cells that were transferred on LB agar plates containing $100 \mu \mathrm{g} / \mathrm{ml}$ sodium ampicillin, $0.25 \mathrm{mM}$ IPTG (Isopropyl $\beta$-d-1-thiogalactopyranoside), and $30 \mu \mathrm{g} / \mathrm{ml}$ X-Gal (5-bromo-4-chloro-3-indolyl- $\beta$-D-galactopyranoside).
Plates were incubated at $37^{\circ} \mathrm{C}$ overnight and positive clones (selected by PCR as described before) were grown in liquid LB containing $100 \mu \mathrm{g} / \mathrm{ml}$ sodium ampicillin at $37^{\circ} \mathrm{C}$ with shaking overnight. DNA plasmidial was extracted from bacterias using PureLink ${ }^{\mathrm{TM}}$ Quick Plasmid Miniprep Kit (Invitrogen $^{\mathrm{TM}}$, Massachusetts, USA). The construct was confirmed by Sanger sequencing (Ludwig Biotecnologia Ltda, Brazil) using BigDye ${ }^{\mathrm{TM}}$ Terminator v3.1 Cycle Sequencing Kit (Applied Biosystems, Massachusetts, USA). For this, recombinant plasmid was sequenced using two PGEM $^{\circledR}-\mathrm{T}$ Easy primers (T7 promoter and pUC/M13 Reverse primers), and three TevXPC specific primers, TevXPC Fwd HindIII, TevXPC Rev Xhol, and TevXPC Int (5'- CCGCTTTTGCGTGC -3'). Basic Local Alignment Search Tool (BLAST) of TriTrypDB was used to corroborate that recombinant plasmid contains a sequence corresponding to TevXPC gene.

\subsection{Gene cloning into pROCK expression vector}

Recombinant pGEM-T-Easy::TevXPC and pROCK expression vector (DaRocha et al., 2004) were digested with restriction enzymes HindIII (New England Biolabs ${ }^{\circledR}$ Inc., Massachusets, USA) and XhoI (Promega ${ }^{\mathrm{TM}}$, Madison, USA). Samples were analyzed by electrophoresis with $1 \%$ low melting gel agarose and fragments of interest were cut and separately purified by the PureLink Quick Gel Extraction Kit (Invitrogen ${ }^{\mathrm{TM}}$, Massachusetts, USA). Ligation was performed with a reaction buffer at $1 \mathrm{X}$ final concentration, $40 \mathrm{ng}$ of pROCK expression vector, $42 \mathrm{ng}$ of TevXPC gene and 2.5 U T4 DNA Ligase (Ludwig Biotecnologia Ltda, Brazil). The ligation product was inserted in Escherichia coli DH10B electrocompetent cells and transferred on LB agar plate containing sodium ampicillin $(100 \mu \mathrm{g} / \mathrm{mL})$. One clone was grown in liquid LB also containing sodium ampicillin at $37^{\circ} \mathrm{C}$ shaking overnight, followed by plasmidial DNA extraction using PureYield ${ }^{\mathrm{TM}}$ Plasmid Maxiprep System (Promega ${ }^{\mathrm{TM}}$, Madison, USA) following the manufacturer's instructions. Recombinant plasmid pROCK::TevXPC was sequenced by Sanger method using TevXPC Fwd HindIII, TevXPC Rev XhoI and TevXPC Int. primers. Confirmation that the sequences corresponded to the TevXPC gene was performed using BLAST TriTrypDB.

\subsection{Parasite transfection}

Epimastigotes forms of T. cruzi strain CL Brener were grown at $28^{\circ} \mathrm{C}$ in liver infusion tryptose (LIT) medium ( $\mathrm{pH}$ 7.4) supplemented with $10 \%$ heat-inactivated fetal bovine serum, penicillin $(100 \mathrm{U} / \mathrm{ml})$, and streptomycin $(100 \mu \mathrm{g} /$ $\mathrm{ml})$. A total of $4 \times 10^{7}$ of these parasites were centrifuged (3,000 rpm, $10 \mathrm{~min}$.$) and the pellet was resuspended$ in electroporation buffer. For transfection, $20 \mu \mathrm{g}$ of pROCK::TevXPC recombinant plasmid was linearized by digestion with restriction enzyme NotI (New England Biolabs ${ }^{\circledR}$ Inc., Massachusets, USA). DNA was precipitated with isopropanol, solubilized in $20 \mu \mathrm{L}$ of $1 \mathrm{X}$ electroporation buffer and added to $T$. cruzi cells for electroporation. One control sample with parasites, but without DNA was also prepared, and parasites were grown as described above at $28^{\circ} \mathrm{C}$ for 24 hours. After this, neomycin was added to a final concentration of $200 \mu \mathrm{g} / \mathrm{ml}$ for $T$. cruzi selection during four weeks. 


\subsection{Confirmation of TevXPC mRNA transcription in $T$. cruzi cells}

RT-PCR was performed to confirm mRNA transcription of TevXPC in transfected cells of T. cruzi (here named TcTevXPC cells). We tested Tc-TevXPC in comparison with WT (wild type) and Tc-TcXPC cells (T. cruzi transfected with pROCK::TcXPC plasmid which were kindly donated by Dr. Isabela Cecília Mendes, UFMG, Minas Gerais, Brazil). For this, total cellular RNA from Tc-TevXPC, WT, and Tc-TcXPC cells was treated with DNAse and tested for non-DNA contamination by PCR. The mixture reaction contained $1.5 \mathrm{U}$ GoTaq ${ }^{\circledR}$ DNA Polymerase (Promega ${ }^{\mathrm{TM}}$, Madison, USA), Colorless GoTaq ${ }^{\circledR}$ Reaction Buffer at $1 \mathrm{X}$ final concentration, $1.5 \mathrm{mM} \mathrm{MgCl}$, $200 \mu \mathrm{M}$ dNTPs, $0.5 \mu \mathrm{M}$ of each primer specifics for TcXPC gene (also donated by Dr. Isabela Cecília Mendes), $150 \mathrm{ng}$ of RNA and nuclease-free water to make up the final volume of $20 \mu \mathrm{L}$. Positive and negative controls contained the same components except that RNA was replaced with $T$. cruzi DNA and nuclease-free water, respectively. The temperature conditions included initial denaturation at $94^{\circ} \mathrm{C}$ for 2 minutes, 30 cycles of $94^{\circ} \mathrm{C}$ for 30 seconds, $64^{\circ} \mathrm{C}$ for 1 minute, and $72^{\circ} \mathrm{C}$ for 2 minutes and 40 seconds, followed by 10 minutes at $72^{\circ} \mathrm{C}$. Amplicons were analyzed through electrophoresis with 1\% gel agarose. SuperScript ${ }^{\mathrm{TM}}$ III First-Strand Synthesis System for RT-PCR (Invitrogen ${ }^{\mathrm{TM}}$, Massachusetts, USA) was used for cDNA synthesis following manufacturer's instructions with oligo(dT) primer. PCR amplification was performed using cDNA from WT, Tc-TcXPC and Tc-TevXPC with the same protocol for non-DNA contamination test in RNA samples. However, this protocol was performed with the following exceptions: positive control contained T. evansi DNA and the specific primers TevXPC Fwd HindIII and TevXPC Rev Xhol were used on reactions.

\subsection{Growth curve under normal conditions and after cisplatin treatment}

In this work, we evaluate the growth of Tc-TevXPC cells in comparison with the growth of WT and Tc-TcXPC cells under normal conditions. Cultures with the same initial parasite concentration were incubated at $28^{\circ} \mathrm{C}$ in liver infusion tryptose (LIT) medium ( $\mathrm{pH}$ 7.4) supplemented with $10 \%$ heat-inactivated fetal bovine serum, penicillin $(100 \mathrm{U} / \mathrm{ml})$, and streptomycin $(100 \mu \mathrm{g} / \mathrm{ml})$ for approximately seven days. Cells were daily counted in a Neubauer chamber using erythrosine vital stain. Experiments were performed in triplicate.

The growth after cisplatin treatment was evaluated in Tc-TevXPC and compared with the growth of WT and TcTcXPC cells also treated with this drug. For this, cultures with the same initial parasite concentration were treated with $300 \mu \mathrm{M}$ of cisplatin and incubated at $28^{\circ} \mathrm{C}$ for 1 hour. After this period, the cells were removed from the LIT medium containing cisplatin and incubated for six days in a new LIT medium without the drug. The cell number was measured by counting as described above. The results were compared to untreated cultures. Experiments were performed in triplicate.

\subsection{Statistical analysis}

Growth and treatment curves graphs were generated in the GraphPad Prism 7.00 program (GraphPad Software Inc., CA, USA). The statistical analyzes were performed using the unpaired $t$ test and $p$-value $<0.05$ was considered as significant.

\section{Results}

\subsection{Percentage of identity between NER proteins from $T$. evansi and other organisms}

Percentage of identity between NER proteins from $T$. evansi and its orthologues from T. brucei, T. cruzi, L. major, S. cerevisiae, and Homo sapiens is shown in Table 2. Among trypanosomatids, T. evansi NER proteins show a higher percentage of identity with their orthologues from $T$. brucei than T. cruzi and L. major. The highest percentage of identity between NER proteins from T. evansi and T. brucei was showed by Pol Delta, RPA1, and TFIIH-Tfb5 (three proteins presented $100 \%$ of identity with E-values $0.0,0.0$ and 8e119 , respectively). The lowest identity percentage was shown by TFIIH-TSP1 protein (98.14\%, E-value: 0.0). In T. evansi and T. cruzi comparison, the highest percentage of identity between NER proteins was showed by TFIIH-XPD (81.09\%, E-value: 0.0), while the lowest was shown by RAD23 (40.92\%, E-value: 3e-78). The highest percentage of identity between NER proteins from $T$. evansi and $L$. major was shown by Pol Delta (74.05\%, E-value: 0.0), and the lowest percentage was presented by p34 (28.37\%, E-value: 2e-28).

\subsection{Comparative analysis of TcXPC, TevXPC, and TbXPC proteins}

Sequences of TevXPC and TbXPC proteins were aligned and displayed 99.61\% identity (E-value: 0.0 ). Sequences of TcXPC and TevXPC proteins showed 52.94\% identity (E-value: 0.0 ) between them. The TcXPC model presented $58 \%$ of coverage, $21 \%$ of identity and $100 \%$ of confidence. For TevXPC, the values were $58 \%$ of coverage, $20 \%$ of identity and $100 \%$ of confidence while TbXPC presented $61 \%$ of coverage, $18 \%$ of identity and $100 \%$ of confidence. In TcXPC, TevXPC, and TbXPC model comparisons was observed that the distance between the "arms" involved in DNA lesion recognition is approximately $16.59 \AA$ in TcXPC (see Figure 1a), $17.36 \AA$ in TevXPC (see Figure 1b) and $23.93 \AA$ for TbXPC (see Figure 1c). We also performed the scheme of TevXPC protein bound to a mismatch DNA (see Figure 1d) and TcXPC, TevXPC and TbXPC models overlay (see Figure 1e). The crystal structure of Rad4-Rad23 bound to a mismatched DNA performed by Min and Pavletich (2007) that was used as template for generation of three-dimensional models is shown in Figure 1f. In domain analysis of TcXPC and TevXPC, three RAD4 beta-hairpin domains were found: BHD1 (predicted by InterPro, Pfam and SMART), BHD2 (predicted by InterPro and SMART) and BHD3 (predicted by InterPro, Pfam and SMART). Furthermore, was found one RAD4/ PNGase transglutaminase-like fold (TGD) predicted by InterPro and Pfam. Domain TGDs from TcXPC and TevXPC 
Table 2. Percentage of identity between NER proteins from T. evansi and its orthologues from T. brucei, T. cruzi, L. major, S. cerevisiae and human. The asterisks indicate that no significant similarity was found $\left({ }^{* * *}\right)$. The ellipsis indicates that there are not homologs found (...).

\begin{tabular}{|c|c|c|c|c|c|}
\hline \multirow[b]{2}{*}{ T. evansi protein } & \multicolumn{5}{|c|}{ Percentage of identity and E-value } \\
\hline & T. brucei & T. cruzi & L. major & S. cerevisiae & Human \\
\hline CSB & $98.93 \% 0.0$ & $55.58 \% 0.0$ & $62.52 \% 0.0$ & $38.65 \% 8 \mathrm{e}-132$ & $42.81 \% 4 \mathrm{e}-147$ \\
\hline DDB1 & $99.06 \% 0.0$ & $54.62 \% 0.0$ & $30.25 \% 2 \mathrm{e}-156$ & $\ldots$ & $18.67 \% 4 \mathrm{e}-17$ \\
\hline ERCC1 & $99.62 \% 0.0$ & $51.89 \% 7 e-93$ & $34.62 \% 2 \mathrm{e}-29$ & $22.34 \% 0.030$ & $30.39 \% 2 \mathrm{e}-09$ \\
\hline DNA ligase I & $99.33 \% 0.0$ & $70.85 \% 0.0$ & $65.81 \% 0.0$ & $41.71 \% 2 \mathrm{e}-175$ & $46.29 \% 0.0$ \\
\hline TFIIH-Tfb4 (p34) & $98.49 \% 0.0$ & $48.18 \% 7 e-93$ & $28.37 \% 2 \mathrm{e}-28$ & *** & *** \\
\hline TFIIH-Ssl1 (p44) & $98.86 \% 0.0$ & $63.81 \% 1 \mathrm{e}-160$ & $37.39 \%$ 3e-94 & $23.39 \% 4 \mathrm{e}-19$ & $22.70 \%$ 6e-22 \\
\hline TFIIH-Tfb2 (p52) & $99.40 \% 0.0$ & $59.12 \% 0.0$ & $42.62 \% 5 e-131$ & $24.05 \% 6 e-17$ & $26.75 \% 8 e-18$ \\
\hline TFIIH-Tfb1 (p62) & $99.45 \% 0.0$ & $51.09 \%$ 4e-112 & $37.37 \% 3 e-70$ & $* * *$ & $25.00 \% 0.024$ \\
\hline $\operatorname{Pol} \delta$ & $100.00 \% 0.0$ & $73.83 \% 0.0$ & $74.05 \% 0.0$ & $45.39 \% 0.0$ & $50.39 \% 0.0$ \\
\hline $\mathrm{Pol} \varepsilon$ & $99.42 \% 0.0$ & $72.34 \% 0.0$ & $60.95 \% 0.0$ & $31.59 \% 0.0$ & $35.21 \% 0.0$ \\
\hline $\operatorname{Rad} 23$ & $99.72 \% 0.0$ & $40.92 \% 3 e-78$ & $30.02 \% 8 \mathrm{e}-48$ & $27.32 \%$ 3e-20 & $26.75 \% 4 \mathrm{e}-15$ \\
\hline RPA1 & $100.00 \% 0.0$ & $77.68 \% 0.0$ & $67.52 \% 0.0$ & $32.57 \%$ 2e-72 & $35.11 \% 5 e-84$ \\
\hline RPA2 & $99.22 \% 0.0$ & $75.42 \%$ 5e-135 & $59.29 \% 1 \mathrm{e}-103$ & $25.10 \% 4 \mathrm{e}-11$ & $30.65 \%$ 4e-24 \\
\hline TFIIH-XPB & $99.89 \% 0.0$ & $68.06 \% 0.0$ & $50.74 \% 0.0$ & $42,34 \% 4 \mathrm{e}-111$ & $42.34 \% 2 \mathrm{e}-105$ \\
\hline XPB-R & $99.49 \% 0.0$ & $65.61 \% 0.0$ & $55.22 \% 0.0$ & $\ldots$ & $\ldots$ \\
\hline $\mathrm{XPC}$ & $99.61 \% 0.0$ & $52.94 \% 0.0$ & $41.68 \% 0.0$ & $22.03 \%$ 6e-11 & $28.14 \% 2 \mathrm{e}-35$ \\
\hline TFIIH-XPD & $99.88 \% 0.0$ & $81.09 \% 0.0$ & $73.28 \% 0.0$ & $40.88 \% 0.0$ & $42.99 \% 0.0$ \\
\hline XPF & $99.11 \% 0.0$ & $42.83 \% 0.0$ & $31.58 \%$ 6e-158 & $26.25 \% 2 \mathrm{e}-21$ & $30.58 \%$ 1e-36 \\
\hline XPG & $99.06 \% 0.0$ & $45.86 \% 3 e-177$ & $40.44 \% 8 \mathrm{e}-75$ & $30.23 \% 1 \mathrm{e}-28$ & $32.57 \%$ 3e-27 \\
\hline TFIIH-Tfb5 & $100.00 \% 8 \mathrm{e}-119$ & $51.80 \% 7 e-43$ & $28.78 \% 3 e-13$ & $\ldots$ & $\ldots$ \\
\hline TFIIH-TSP1 & $98.14 \% 0.0$ & $49.17 \%$ 7e-156 & $30.70 \% 2 \mathrm{e}-69$ & $\ldots$ & $\ldots$ \\
\hline TFIIH-TSP2 & $99.54 \% 0.0$ & $55.83 \% 4 \mathrm{e}-176$ & $31.45 \%$ 9e-67 & $\ldots$ & $\ldots$ \\
\hline HuF2 & $99.61 \% 0.0$ & $70.97 \% 0.0$ & $66.32 \% 0.0$ & $28.70 \% 2 \mathrm{e}-62$ & $29.70 \% 3 e-62$ \\
\hline
\end{tabular}

presented 67.53\% identity (E-value: 2e-42). Additionally, it was performed on a comparison between TcXPC and TevXPC domains (see Figure 2a).

\subsection{Comparative analysis of TCRAD23 and TevRAD23 proteins}

Full-length alignment between TcRAD23 (RAD23 from T.cruzi) and TevRAD23 (RAD23 from T. evansi) revealed 40.92\% identity (E-value: 3e-78). Domain analysis showed that TcRAD23 (361 amino acids length) contains one ubiquitin-like domain (UBL) located on the amino acid 1 to 74 (predicted by InterPro and PROSITE), one XPC-binding domain (R4BD) from the amino acid 236 to 289 (predicted by InterPro and Pfam), and ubiquitinassociated domains (UBA). About the last, InterPro predicted that TcRAD23 contains only one UBA (amino acid 149 to 358) while two UBA domains were predicted by SMART (amino acid 151 to 189 and 317 to 357), Pfam (amino acid 151 to 187 and 320 to 352) and PROSITE (amino acid 149 to 190 and 314 to 358). TevRAD23 (356 amino acids length) also presents one domain UBL predicted by InterPro and PROSITE (amino acid 1 to 74), SMART (amino acid 1 to 70 ) and Pfam (amino acid 5 to 71). One domain UBA was predicted by InterPro and PROSITE (amino acid 141 to 182), SMART (amino acid 143 to 181) and Pfam (amino acid 143 to 179). One R4BD domain was predicted by InterPro and Pfam (amino acid 228 to 280). The R4BDs from TcRAD23 and TevRAD23 presented 41.18\% identity (E-value: 4e-12). The three-dimensional models for TcRAD23 and TevRAD23 were performed, but more than $50 \%$ of the sequences were predicted disorderly and these regions cannot be meaningfully predicted.

\subsection{Comparative analysis of Tcp62 and Tevp62 proteins}

Tcp62 (p62 from T. cruzi) and Tevp62 (p62 from T. evansi) alignment revealed 51.09\% identity (E-value: $4 \mathrm{e}-$ 112 ) between them. In analysis using ScanProsite, was not found in TevXPC and TcXPC proteins sequences studied in this work, a sequence motif involved in binding with p62 as Okuda et al. (2015) describe for Human XPC and 
(a)

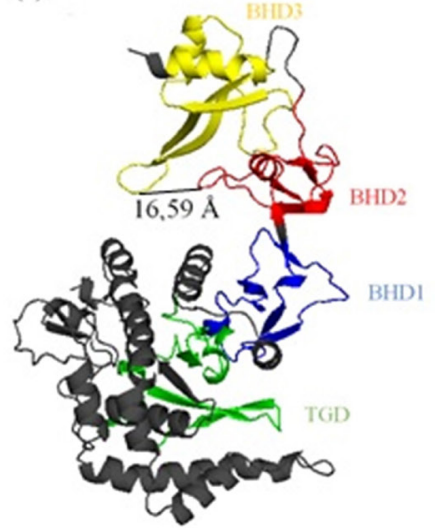

(c)

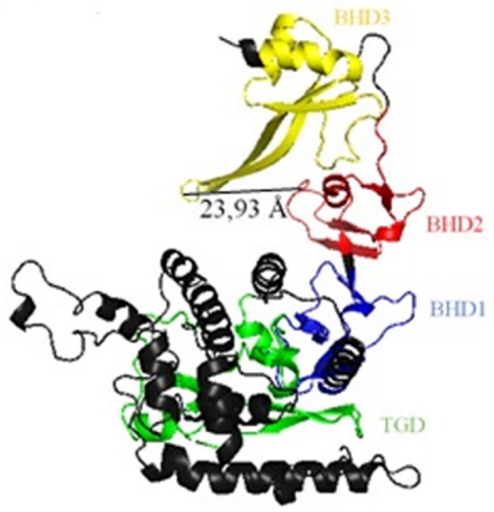

(e)

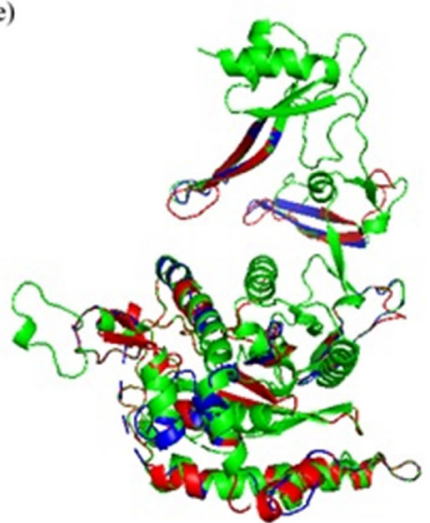

(b)

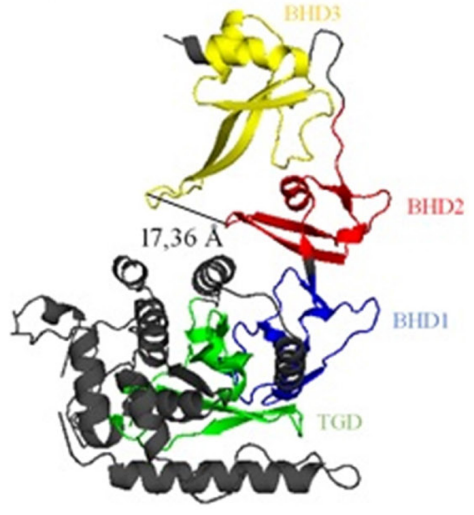

(d)

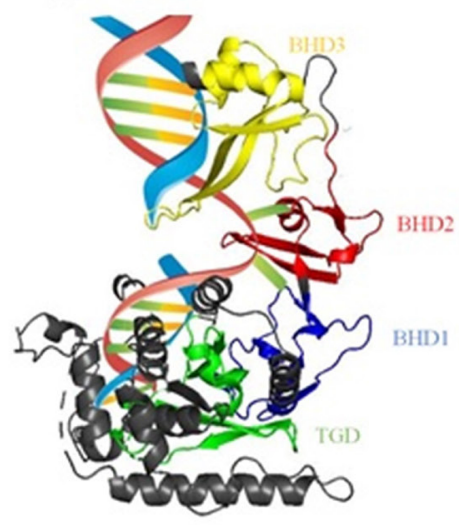

(f)

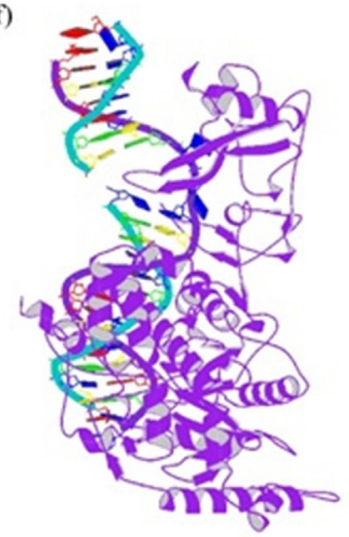

Figure 1. (a) TcXPC protein model. (b) TevXPC protein model. (c) TbXPC protein model(d) Model of TevXPC protein bound to a mismatch DNA. (e) TcXPC (red), TevXPC (blue) and TbXPC (green) models overlay. (f) Crystal structure of Rad4-Rad23 bound to a mismatched DNA performed by Min and Pavletich (2007).

yeast RAD4: D/E-F/W-E-D/E-V. However, we noticed in TevXPC (see Figure $2 b$ ), one sequence (E-W-E-E-V) with high similarity with the sequence previously described. About TcXPC, the candidate sequence (E-W-D-E-V) contains one amino acid change in the third position that differs from the motif already described by Okuda et al. (2015).
3.5. Comparative analysis of TCXPB, TevXPB, TcXPB-R, and TevXPB-R proteins

Alignment of proteins TcXPB (XPB from T. cruzi) and TevXPB (XPB from T. evansi) showed a $68.06 \%$ identity (E-value: 0.0 ) between them. The three-dimensional models of TcXPB (see Figure 3a) and TevXPB (see Figure 3b) 
(a) TcXPC 1 MHFFFFFFLP LHCNNNNGAE RRGWWCLLLA FRGGIMNESK QEGKKRNVAA AAAANVDGYL RNASRRVRIP SASGGRGTRR

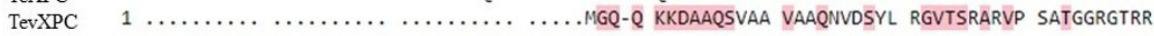

TcXPC 81 KLAMVTAASV -EQASRPVVN TNTSDAVDLD DEWDEVVLPN ANAAAVKK-D EGKLKKE--E SSQKPKMDVP VANSCAGSIK TeVXPC 45 RLASQAEVAA AKIKEQPKSL DDFADADNGD DEWEEVMLPT SFTPSSSTKP EVKVKDEKNG IVETPEFGAT GPNPGQGSVK

TcXPC 157 AEALEVEDGE WVGGDEDSA QSLMEGTRPP LTGTSIQRWR RNEHFQERMP EQQQILAAQR RSERIRRAAE GMSVLIFALQ TevXPC 125 AELVDLTDEE NRHNRILAS- VTPMGG--QQ SSSPSSGQWR QRDPAYEQML EQQQLLAAKR RSERTKRAVE EISTLLFALL

TCXPC 237 RCKTLVRESR YPQLLRKLLR VCTVEVNGSK SFPFIQAVQR AREEYQRALD PAVKNPALSP CWVTVGKDTV RNYTSNSIMA TeVXPC 202 RGRKIVQQAR HPKLVRGLLR LYVEDATSK TYPLLRAVLQ AKGLYAKAMN PAVSTPSLAP CWVTANKDSV NNYTSASISA

TCXPC 317 LFSGITTVFT LEDKVDASIL SNWAAPISFG HLSNLLSRSH QFLISPDAKL PLPHSLYFSI IFLSVANILG MSCRLVMAIK TeVXPC 282 LLRGIECVFV LDGGIEHAAL SNWAAPIQPG YLFEQLRKYR YSIGSPGCRI VLPHSLYICA VFLSLAAVSN VSCRLVVAVE

TCXPC 397 KERERQNPVV TENGNVSEKP AQMTIFLPRV KRQRKEGANE EDKLPQKLPS SCFWVEVWCP QRESFISVNP CKGCTALWGA TevXPC 362 RMRRGDMSEK SGSDGGSPPK EAMSLFGSGK KRKRGDDAGA KQNTPKRLPS SCFWLEVWCP QRQSYISVNP CGGCATLFAA

TCXPC 477 PYTFSVGGDV AMDVTPRYTT KYSSAFTYRW GRCDSYRFLW KHLDWNDTRE ASEVILDAFR KDMTRNTCIQ LARERRQLHS TevXPC 442 PYTFSVGGDA IMDVTPRYSI KYSSAFTHRL GRCDRYRHIW KDLQWNDNRE ASEVIVDLFR RDVGKYTEAQ MQREKKQLHS

TCXPC 557 LTYAEEIPKT LTALHKHPLF VLENELARHE GVYPKDNTTI VGSVKGHTVY KRSAVVNLRS RDGWLRVGRC VVSEDEAPYK TeVXPC 522 LTYAEEVPKT LTALQKHPLF ILENGLSRYE GIYPKDSTTM VGSVKGHIVF KRSAVVSLRS RDGWLREGRT VS-GEEEPYK

TCXPC 637 VVPPPASRPF GSSSGFFGVW QTKPFEPSPL RSDGSLPLHG KTRWYVLLGK PVPEGLAYIQ RPNIARVARL VDVEFGHAVM TevXPC 601 VIPPPPSRPF SKSSALFGVW QTKPFAPEPL GEDGSIPKHG NTQWYILLDK PAPIGLVHMQ QPNIIRVARR MNIDFGIVT

TcXPC 717 GFQRRRLDER RFSHWEAVFD GIWREADAA NLLHAYDEWR QLTEEQEATK RRQRANRWWL HFVQRMLAMQ RVRQQYLDGA TevXPC 681 GYRRRRLNEA RSSGWEWTID GIIVKETNTG SLVKAYEEWK QLTEEQEAAK RKQRAYRWWM HFVQHRLAYL RIRQQYLEGA

\section{TcXPC 797 SHGYLPLH}

TevXPC 761 THGHLSSH

$\begin{array}{ll}\text { (b) TCXPC } & \text { TNTSDAVDLD DEWDEV VLPN ANAAAVKK-D } \\ \text { TEVXPC } & \text { DDFADADNGD DEWEEV ILPT SFTPSSSTKP }\end{array}$

Figure 2. (a) Alignment between TcXPC and TevXPC proteins (mismatches highlighted) and its domains. Green: RAD4/PNGase transglutaminase-like fold. Blue: RAD4 beta-hairpin domain 1. Red: RAD4 beta-hairpin domain 2. Yellow: RAD4 beta-hairpin domain 3. (b) Candidate sequence motif involved in p62 interaction (highlighted by brown rectangle) found in TcXPC and TevXPC. This sequence is suggested based on the sequence motif described for Human XPC and yeast RAD4: D/E-F/W-E-D/E-V.
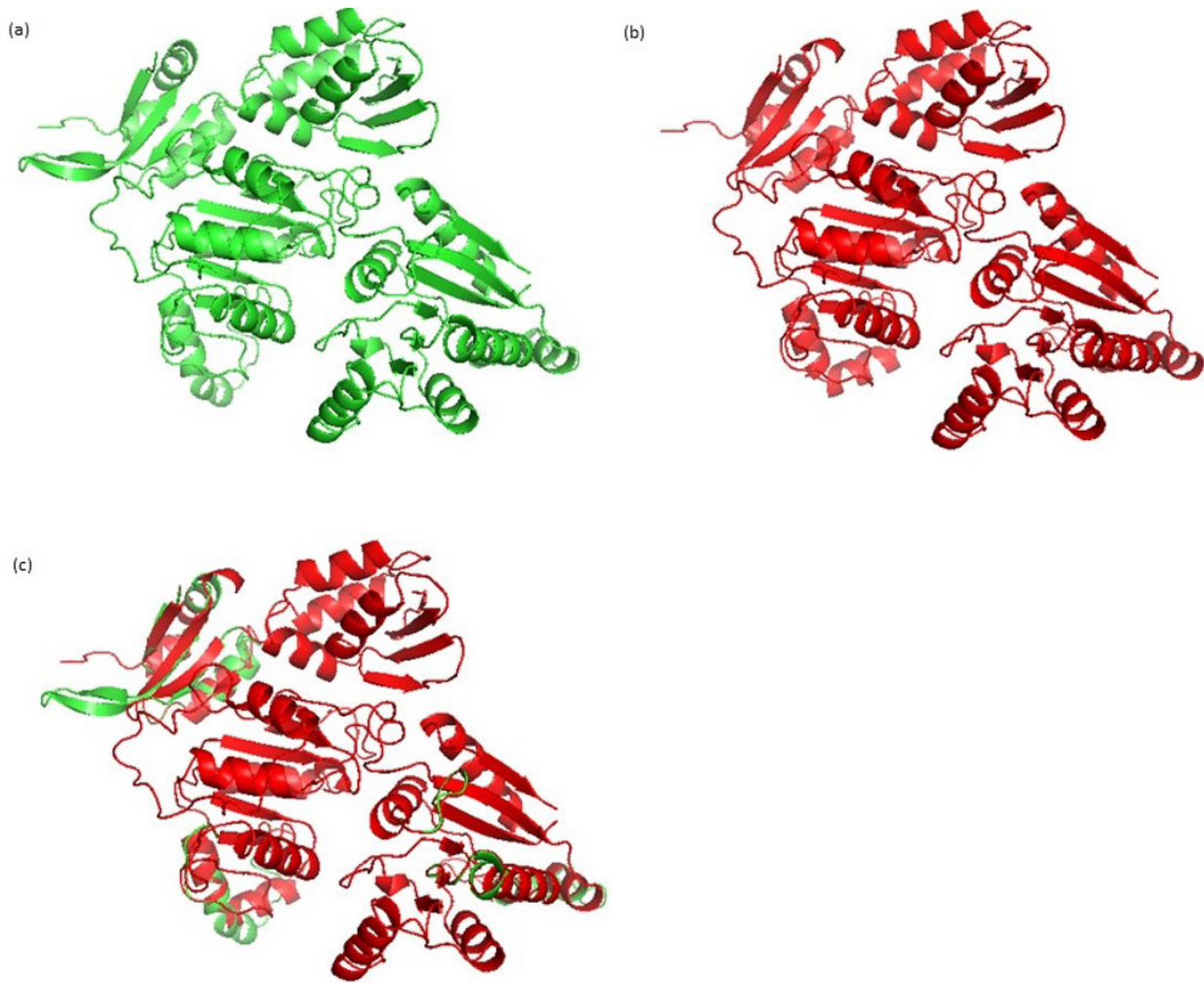

Figure 3. (a) TcXPB protein model. (b) TevXPB protein model. (c) TcXPB (green) and TevXPB (red) models overlay. 
proteins were performed. The TcXPB model presented $62 \%$ of coverage, $36 \%$ of identity and $100 \%$ of confidence while the TevXPB model presented 61\% of coverage, 38\% of identity and $100 \%$ of confidence. In model overlays of TcXPB and TevXPB (as shown in Figure 3c), the proteins showed high similarity.

Alignment of proteins TcXPB-R (XPB-R from T. cruzi) and TevXPB-R (XPB-R from T. evansi) showed $65.61 \%$ identity (E-value: 0.0 ) between them. Three-dimensional models of TcXPB-R (Figure 4a) and TevXPB-R (Figure 4b) were performed. The three-dimensional model of TcXPB-R presented $77 \%$ of coverage, $38 \%$ of identity and $100 \%$ of confidence while the TevXPB-R model presented 73\% of coverage, $36 \%$ of identity and $100 \%$ of confidence. In overlapping models of TcXPB-R and TevXPB-R (Figure 4c), the proteins showed high similarity.

\subsection{Tc-TevXPC cells present growth difficulties}

TevXPC gene was amplified by PCR and cloned into pGEM $^{\circledast}-\mathrm{T}$ Easy vector (Promega ${ }^{\mathrm{TM}}$, Madison, USA) followed by Sanger sequencing using two primers designed to be annealed to $\mathrm{pGEM}^{\circledR}$-T Easy and three gene specific primers. The Figure S1 a shows the result obtained using one vector specific primer (T7 promoter) as an example. The cloned TevXPC gene is $100 \%$ identical to the database TevXPC sequence (Supplementary Material Figure S1b). Thereafter, TevXPC was subcloned in pROCK vector (DaRocha et al., 2004) and recombinant plasmid was sequenced by Sanger method using three gene specific primers. Figure $\mathrm{S} 2$ a shows the result obtained using the TevXPC Int. primer as an

(a)

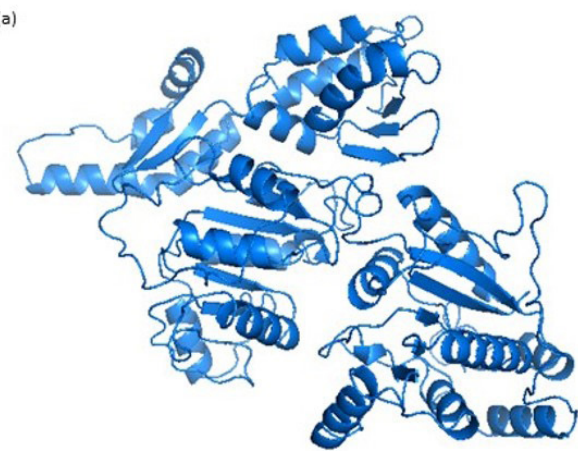

(c)

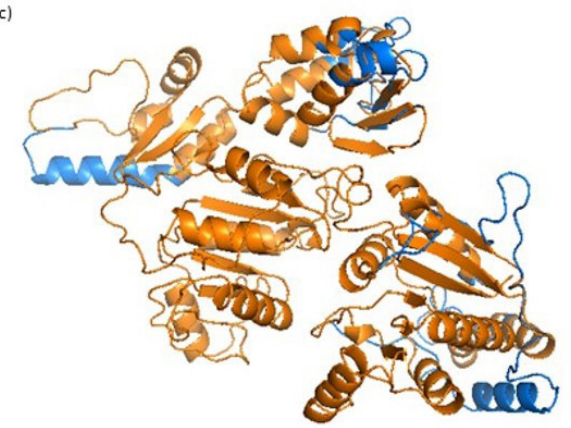

example. The sequencing result confirmed the insertion of TevXPC in pROCK vector (Figure S2b). Recombinant plasmid pROCK::TevXPC was introduced in T. cruzi cells and the resultant recombinant strain presented growth difficulties after transfection. Analysis by RT-PCR (Figure 5) showed TevXPC amplification from cDNA of the Tc-TevXPC cells. There was no amplification from cDNA of WT and Tc-TcXPC cells as expected.

For testing the growth curve, parasite cultures of TcTcXPC and Tc-TevXPC cells were analyzed in comparison to WT growth (Figure 6). The Tc-TcXPC cell grew more slowly than WT in a period of the curve: in three points of the curve, Tc-TcXPC grew significantly less than WT (p $<0.05$ ), but there was no significant difference in growth between them on others four points ( $p>0.05$ ). Tc-TevXPC cells showed a remarkable growth rate slower than WT: only at day 1 of the curve there was no significant difference in growth between Tc-TevXPC and WT ( $p>0.05)$, but all other days Tc-TevXPC grew significantly less than WT ( $p$ $<0.05$ ). After cisplatin treatment (Figure 7), WT and TcTevXPC treated cells presented significantly lower growth in comparison with the same cells untreated: only at day 1 of the curve there was no significant difference $(p>0.05)$ between growth of WT treated and WT untreated cells or Tc-TevXPC treated and Tc-TevXPC untreated, but in all other days, cells treated with cisplatin grew significantly less than its respective untreated cells $(\mathrm{p}<0.05)$. Tc-TcXPC cells treated with cisplatin also grew less than Tc-TcXPC untreated cells. However, the growth curve difference between these two cultures was not significant in all points of the curve $(p>0.05)$.

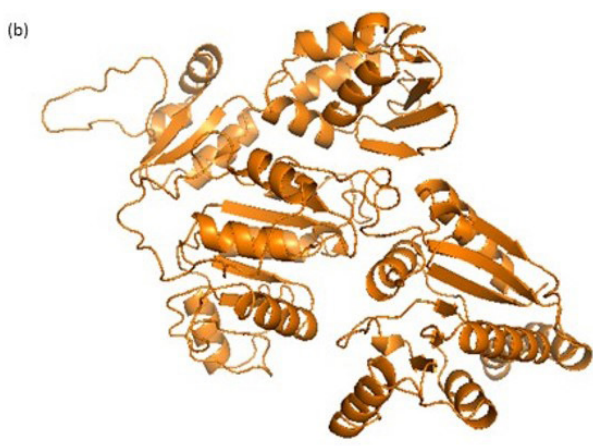

Figure 4. (a) TcXPB-R protein model. (b) TevXPB-R protein model. (c) TcXPB-R (blue) and TevXPB-R (orange) models overlay. 


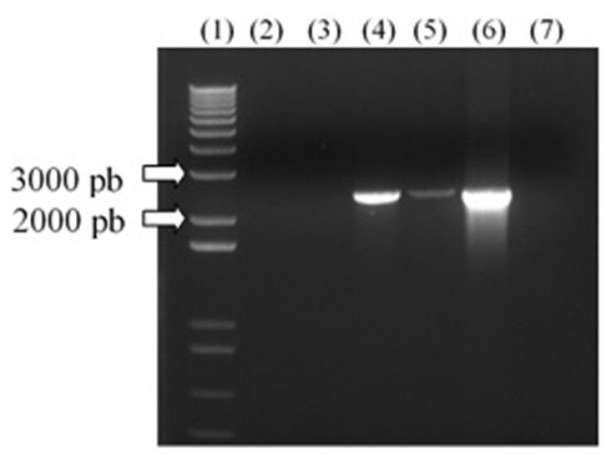

Figure 5. TevXPC amplification by RT-PCR with the cDNA from cell cultures. Lanes: (1) 1Kb DNA Ladder; (2) WT; (3) Tc-TcXPC; (4 and 5) Tc-TevXPC; (6) positive control (DNA from T. evansi); (7) negative control.

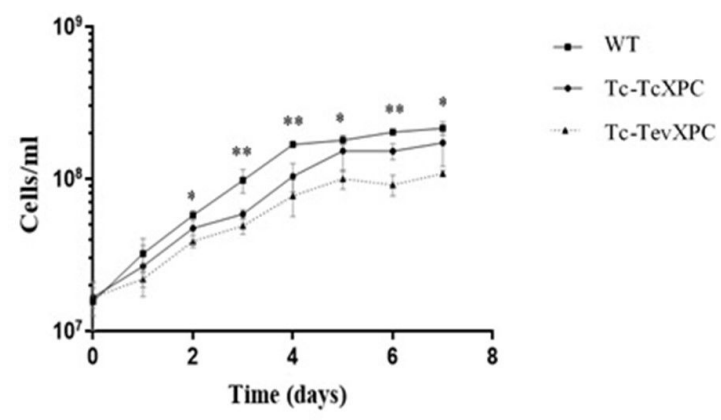

Figure 6. Growth assessment of T. cruzi: wild type (WT), TcXPC superexpressor (Tc-TcXPC) and TevXPC expressor (Tc-TevXPC). Statistical student's t test: $\left({ }^{*}\right)$ On that point, only Tc-TevXPC presented a statistically significant lower growth in relation to WT (p < 0.05); $\left(^{* *}\right)$ On that point, both Tc-TcXPC and Tc-TevXPC presented a significant lower growth in relation to WT $(\mathrm{p}<0.05)$. All parasites were at same initial concentration, grown on LIT medium and were counted daily. Representative results of three independent experiments.

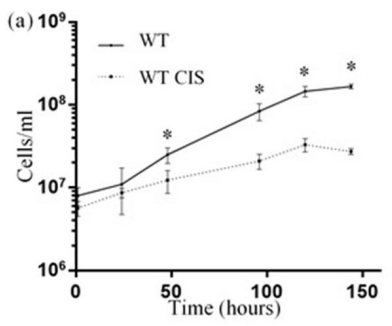

\section{Discussion}

Trypanosomatids present several highly diverged biological processes and T. cruzi, T. brucei, and Leishmania $s p$ are among the most studied species of this family (Machado et al., 2014). T. cruzi, T. brucei and L. major show some remarkable NER differences from the higher eukaryotes. For instance, they do not present a recognizable ligase III, DBB2, XPA, CSA, and RPA3 genes (Passos-Silva et al., 2010). In humans' cells, severe consequences are observed if there is missfunction in ligase III (Kohutova et al., 2019), DDB2 (Yoon et al., 2005), XPA (Messaoud et al., 2012; Manandhar et al., 2017), CSA (D'errico et al., 2007) or RPA3 (Dai et al., 2017) protein. Further, T. cruzi, T. brucei and L. major have duplication of XPB gene (Passos-Silva et al., 2010). On the TriTrypDB database we verified that in $T$. evansi two XPB-like proteins were also present while DDB2, $\mathrm{XPA}, \mathrm{CSA}, \mathrm{RPA} 3$ and ligase III were not found. Furthermore, T. cruzi, T. brucei and L. major contain two trypanosomatidspecific subunits of TFIIH: TSP1 and TSP2 (Passos-Silva et al., 2010) that are also present in T. evansi.

We verified the percentage of identity between NER proteins from T. evansi, T. brucei, T. cruzi, L. major, S. cerevisiae, and human (as shown in Table 2) and the majority of trypanosomatids NER proteins studied in this work have orthologues in S. cerevisiae and humans. Among trypanosomatids, NER proteins from T. evansi show a higher percentage of identity with their orthologues in T. brucei than T. cruzi and L. major. It is important to emphasize that in genus Trypanosoma, the T. evansi and T. brucei (that presented the highest identity between their NER proteins) are classified into the subgenus Trypanozoon, while T. cruzi is classified in subgenus Schizotrypanum (Baral, 2010). The L. major, whose NER proteins presented the lowest identity with the orthologs in T. evansi, is classified in the same family as T. evansi, T. cruzi and T.brucei, but not in the same genus (Hamilton et al., 2004).

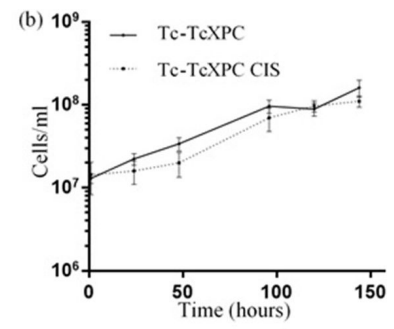

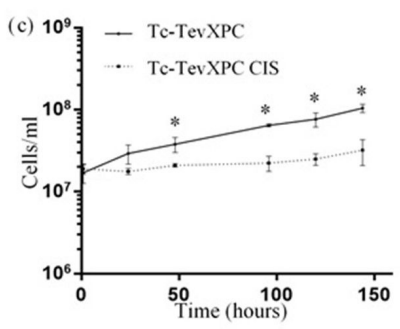

Figure 7. T. cruzi growth assessment after cisplatin treatment (300 $\mu \mathrm{M})$ ). (a) Wild type (WT). (b) TcXPC superexpressor (Tc-TcXPC). (c) TevXPC expressor (Tc-TevXPC). The solid lines represent the untreated cells, while the dotted lines represent the cells treated with cisplatin. Statistical student's t test: $\left(^{*}\right)$ On that point, cells treated with cisplatin presented a statistically significant lower growth in relation to untreated cells $(\mathrm{p}<0.05)$. Representative results of three independent experiments. 
Another focus of this work was the investigation about XPC protein in T. evansi and T. cruzi. This protein acts on the recognition of UV DNA lesions and other bulky DNA adducts on the GG-NER (Kemp and Hu, 2017). It is known that human XPC plays a role in many pathways within cells, such as proteolysis and post-translational modifications, transcription regulation, signal transduction, metabolism, DNA repair and replication (Lubin et al., 2013). Further, studies have found that XPC is also involved in base excision repair, chromatin remodeling, cell signaling, proteolytic degradation, and cellular viability (Nemzow et al., 2015).

In TcXPC, TevXPC and TbXPC model comparisons it was observed that the distance between the "arms" involved in DNA lesion recognition is approximately $16.59 \AA$ for TcXPC (see Figure 1a), $17.36 \AA$ in TevXPC (see Figure 1b) and $23.93 \AA$ for TbXPC (see Figure 1c). The fact that these distances are more similar between TevXPC and TcXPC is surprising since TevXPC and TbXPC amino acid sequences showed 99.61\% identity (E-value: 0.0), while TevXPC and TcXPC showed 52.94\% identity (E-value: 0.0). It is important to highlight that the few differences between amino acid sequences from TevXPC and TbXPC are not located in the domains of these proteins. However, it seems that these changes were enough to present differences between the structures of the lesion recognition site in models performed for these two proteins. We performed a scheme of TevXPC protein bound to a mismatched DNA (see Figure 1d) and an overlapping model of TcXPC, TevXPC and TbXPC (see Figure 1e). Overlapping showed that the three models present a highly similar structure between them with few differences. Furthermore, these three models also presented similarity with Crystal structure of yeast Rad4-Rad23 bound to a mismatched DNA (see Figure 1f) performed by Min and Pavletich (2007). Rad4-Rad23 is the yeast ortholog of human XPC-RAD23B complex (Krasikova et al., 2013). Likewise, Machado et al. (2014) also performed a TbXPC model and observed a distance of 27 Å between "arms" on the lesion recognition site. The author suggested that because the DNA double helix is approximately $20 \AA$, it is plausible that TbXPC may bind to two DNA strands while RAD4 that presents $13 \AA$ can only recognize one DNA strand. Considering this, we suggest that is possible that the DNA binding mechanism has differences between TcXPC, TevXPC and TbXPC, because it is probable that TcXPC and TevXPC can recognize only one DNA strand while TbXPC can recognize both DNA strands.

Evaluation of TevXPC expression effects on T. cruzi cells was performed through TevXPC gene insertion in T. cruzi. The growth of modified cells was analyzed in comparison to WT cell growth. The tests were performed under normal conditions of culture as well as after cisplatin treatment. Under normal conditions, Tc-TevXPC cells presented remarkable growth difficulty in relation to WT. This suggests that TevXPC gene insertion in T. cruzi cells may have altered one or more cellular processes of this parasite. Although TcXPC and TevXPC are orthologous, it is believed that exogenous TevXPC protein interacts in one or more T. cruzi cellular processes wherein endogenous TcXPC protein plays a role. However, TevXPC is not able to work efficiently in T. cruzi cells. Therefore, it must have occurred some disorder in the cellular processes of $T$. cruzi wherein $\mathrm{XPC}$ protein is involved, resulting in altered cell growth.

In addition to remarkable difficulty growth of Tc-TevXPC under normal conditions, a slight lower cell growth was also observed in Tc-TcXPC cells when compared with WT. It is possible that excessive XPC protein in Tc-TevXPC and Tc-TcXPC cells results in the greater interaction of this protein with DNA, which can delay normal cell growth.

In the growth curve after cisplatin treatment, Tc-TevXPC cells presented more difficulty in growth when compared with other cells. While treated WT and Tc-TcXPC cells showed an increase in the cellular population during the days of observation, the treated Tc-TevXPC cells did not show an increase in the number of cells within 124 hours. This suggests that if exogenous TevXPC can recognize DNA lesions in Tc-TevXPC cells, the possible lack of interaction between exogenous TevXPC and endogenous NER proteins in Tc-TevXPC cells results in no repair of DNA damage. Besides not working efficiently in DNA repair, exogenous TevXPC when binds to damaged DNA, takes the place of endogenous TcXPC on the site of lesion and does not allow that endogenous protein works in DNA repair.

We analyzed the amino acids sequences of TcXPC and TevXPC as well as the amino acids sequences from NER proteins that interact with them. Domain analysis showed three RAD4 beta-hairpin domains (BHD1, BHD2, and BHD3) and one RAD4/PNGase transglutaminase-like fold (TGD) in TevXPC and TcXPC proteins (see Figure $2 \mathrm{a}$ ). It is predicted that RAD4/XPC proteins do not have transglutaminase enzymatic activity due to the disruption of the active site triad (Anantharaman et al., 2001), but TGD acts in DNA repair (Min and Pavletich, 2007). In RAD4 protein, the domains TGD and BHD1 bind to DNA undamaged segments, while BHD2 and BHD3 bind to DNA segments that contain cyclobutane pyrimidine dimer lesion. In addition, TGD from RAD4 also interacts with UBA2 and R4BD of RAD23 protein (Min and Pavletich, 2007). During GG-NER, mammalian RAD23 protein enhances the binding of XPC to DNA damage besides stabilizing XPC (Bergink et al., 2012). Domain TGDs from TcXPC and TevXPC presented 67.53\% identity (E-value: 2e-42) while R4BDs from TcRAD23 and TevRAD23 presented 41.18\% identity (E-value: 4e-12). In domain analysis, InterPro predicted a single UBA domain in TcRAD23, but Pfam, PROSITE and SMART predicted two UBA domains. It is important to note that the single UBA predicted by InterPro covers the regions of two UBA domains predicted by other databases. Regarding TevRAD23, only one UBA was predicted by InterPro, Pfam, PROSITE and SMART in this protein. Considering the differences between these domains of XPC and RAD23 proteins from T. cruzi and T. evansi, it is possible that in Tc-TevXPC cells, exogenous TevXPC protein could not interact with endogenous TcRAD23.

After DNA lesion recognition, XPC prepares the damaged site for TFIIH recruitment and excision of damaged DNA (Compe and Egly, 2012). TFIIH is recruited by XPC through interactions involving the p62 and XPB subunits of TFIIH (Yokoi et al., 2000). According to Badjatia et al. (2013), kinetoplastid organisms contain two divergent XPB paralogues (XPB and XPB-R). In other hand, in T. brucei only XPB was identified as a TFIIH subunit and is also suspected that in trypanosomes the NER machinery is 
separate from the TFIIH complex while XPB-R does not function in transcription but acts in NER (Badjatia et al., 2013). Three-dimensional models of TcXPB (see Figure 3a) and TevXPB (see Figure 3b) were performed and in overlapping these two models it was observed that TcXPB and TevXPB structures are highly similar between them (as shown in Figure 3c). In our alignment analysis, proteins TcXPB and TevXPB showed 68.06\% identity (E-value:0.0). Three-dimensional models of TcXPB-R (see Figure 4a) and TevXPB-R (see Figure 4b) also present high similar structure between them (as shown in Figure 4c). Alignment of proteins TcXPB-R and TevXPB-R showed $65.61 \%$ identity (E-value:0.0) between these two proteins. It is possible that although XPB proteins form $T$. cruzi and $T$. evansi are similar, TFIIH was not recruited due to impairment in TevXPC interaction with TcXPB or TcXPB-R proteins.

Regarding XPC interaction with p62, human XPC and yeast RAD4 contain a common motif involved in binding with p62 (Okuda et al., 2015). We found a candidate sequence motif for interaction with p62 in TevXPC. However, in TcXPC the corresponding sequence contains one amino acid change in the third position that differs from the motif already described (as shown in Figure 2b). Proteins Tcp62 and Tevp62 display 51.09\% identity (E-value: $4 \mathrm{e}-112$ ). It is possible that if exogenous TevXPC could recognize a DNA lesion in $T$. cruzi cells, it was not able to interact with endogenous Tcp62 due to some differences in relation to Tevp62. This lack of interaction between TevXPC and Tcp62 also may have occurred because motifs of interaction with p62 and surrounding regions in TcXPC and TevXPC have some differences. Thus, if TevXPC did not interact with Tcp62, probably TFIIH was not recruited for damage excision. Therefore, DNA damage recognition by TcXPC in T. cruzi cells is effective in TFIIH recruitment and DNA repair, but if TevXPC (being an exogenous XPC protein) binding to a DNA distortion, it is probably that TFIIH is not recruited due impaired interaction of exogenous XPC with the $T$. cruzi NER proteins and DNA repair does not occur.

\section{Conclusion}

In conclusion, although the three-dimensional models performed for TcXPC and TevXPC showed a highly similar structure between them, it is suggested that the identity between these proteins was not sufficient for establish TevXPC function in T. cruzi. The TevXPC gene insertion in $T$. cruzi cells decreased their growth. This suggests that TevXPC protein acted as a dominant negative element within $T$. cruzi cells due taking the place of endogenous TcXPC protein in one or more cellular processes, but is not able to continue the process (or processes). Probably because TevXPC is able to interact with some molecules, but is unable to interact with other factors due to some threedimensional and/or chemical incompatibility. Another fact observed in our study was that Tc-TevXPC cells did not respond to cisplatin treatment similarly to Tc-TcXPC cells, possibly suggesting that TevXPC recognizes lesions in DNA, but is not able to direct de damage for repair. Therefore, these tests show the importance of correctly XPC functioning within the cell.

\section{Acknowledgements}

For financial support: Conselho Nacional de Desenvolvimento Científico e Tecnológico (CNPq), (Chamada MCTI/CNPQ/UNIVERSAL 14/2014, Processo 459918/2014-1); Fundação de Amparo à Pesquisa e Inovação do Estado de Santa Catarina (FAPESC), (Editais CP 04/2018 PAP UDESC e 27/2020 - Apoio à Infraestrutura para Grupos de Pesquisa da UDESC). Ketriane Mota de Souza was a fellowship of Coordenação de Aperfeiçoamento de Pessoal de Nível Superior (CAPES). To Paulo Henrique Exterchoter Weiss, in memoriam.

\section{References}

ANANTHARAMAN, V., KOONIN, E.V. and ARAVIND, L., 2001. Peptide-N-glycanases and DNA repair proteins, $\mathrm{Xp}-\mathrm{C} / \mathrm{Rad} 4$, are, respectively, active and inactivated enzymes sharing a common transglutaminase fold. Human Molecular Genetics, vol. 1, no. 10, pp. 1627-1630. http://dx.doi.org/10.1093/hmg/10.16.1627. PMid:11487565.

ASLETT, M., AURRECOECHEA, C., BERRIMAN, M., BRESTELLI, J., BRUNK, B.P., CARRINGTON, M., DEPLEDGE, D.P., FISCHER, S., GAJRIA, B., GAO, X., GARDNER, M.J., GINGLE, A., GRANT, G., HARB, O.S., HEIGES, M., HERTZ-FOWLER, C., HOUSTON, R., INNAMORATO, F., IODICE, J., KISSINGER, J.C., KRAEMER, E., LI, W., LOGAN, F.J., MILLER, J.A., MITRA, S., MYLER, P.J., NAYAK, V., PENNINGTON, C., PHAN, I., PINNEY, D.F., RAMASAMY, G., ROGERS, M.B., ROOS, D.S., ROSS, C., SIVAM, D., SMITH, D.F., SRINIVASAMOORTHY, G., STOECKERT, C.J. Jr., SUBRAMANIAN, S., THIBODEAU, R., TIVEY, A., TREATMAN, C., VELARDE, G. and WANG, H., 2010. TriTrypDB: a functional genomic resource for the Trypanosomatidae. Nucleic Acids Research, vol. 38, suppl. 1, pp. 457-462. http://dx.doi.org/10.1093/nar/gkp851. PMid: 19843604.

BADJATIA, N., NGUYEN, T.N., LEE, J.H. and GÜNZL, A., 2013. Trypanosoma brucei harbours a divergent XPB helicase paralogue that is specialized in nucleotide excision repair and conserved among kinetoplastid organisms. Molecular Microbiology, vol. 90, no. 6, pp. 1293-1308. http://dx.doi.org/10.1111/mmi.12435. PMid:24134817.

BARAL, T.N., 2010. Immunobiology of African trypanosomes: need of alternative interventions. Journal of Biomedicine E Biotechnology, vol. 2010, pp. 389153. http://dx.doi.org/10.1155/2010/389153. PMid:20182644.

BERGINK, S., TOUSSAINT, W., LUIJSTERBURG, M.S., DINANT, C., ALEKSEEV, S., HOEIJMAKERS, J.H., DANTUMA, N.P., HOUTSMULLER, A.B. and VERMEULEN, W., 2012. Recognition of DNA damage by XPC coincides with disruption of the XPC-RAD23 complex. The Journal of Cell Biology, vol. 196, no. 6, pp. 681-688. http://dx.doi.org/10.1083/jcb.201107050. PMid:22431748.

BERMAN, H.M., WESTBROOK, J., FENG, Z., GILLILAND, G., BHAT, T.N., WEISSIG, H., SHINDYALOV, I.N. and BOURNE, P.E., 2000. The Protein Data Bank. Nucleic Acids Research, vol. 28, no. 1, pp. 235242. http://dx.doi.org/10.1093/nar/28.1.235. PMid:10592235.

BERN, C., 2015. Chagas' Disease. The New England Journal of Medicine, vol. 30, no. 5, pp. 456-466. http://dx.doi.org/10.1056/ NEJMra1410150. PMid:26222561.

BIANCHI, T.F., JESKE, S., SARTORI, A., GRALA, A.P. and VILLELA, M.M., 2021. Validation of a documentary on Chagas disease by a population living in an endemic area. Brazilian Journal of Biology = Revista brasleira de Biologia, vol. 81, no. 3, pp. 665-673. https://doi.org/10.1590/1519-6984.228876. 
BLUM, M., CHANG, H.Y., CHUGURANSKY, S., GREGO, T., KANDASAAMY, S., MITCHELL, A., NUKA, G., PAYSAN-LAFOSSE, T., QURESHI, M., RAJ, S., RICHARDSON, L., SALAZAR, G.A., WILLIAMS, L., BORK, P., BRIDGE, A., GOUGH, J., HAFT, D.H., LETUNIC, I., MARCHLER-BAUER, A., MI, H., NATALE, D.A., NECCI, M., ORENGO, C.A., PANDURANGAN, A.P., RIVOIRE, C., SIGRIST, C.J.A., SILLITOE, I., THANKI, N., THOMAS, P.D., TOSATTO, S.C.E., WU, C.H., BATEMAN, A. and FINN, R.D., 2021. The InterPro protein families and domains database: 20 years on. Nucleic Acids Research, vol. 49, no. 1, pp. 344-354. http://dx.doi.org/10.1093/ nar/gkaa977. PMid:33156333.

COMPE, E. and EGLY, J.M., 2012. TFIIH: when transcription met DNA repair. Nature Reviews. Molecular Cell Biology, vol. 13, no. 6, pp. 343-354. http://dx.doi.org/10.1038/nrm3350. PMid:22572993.

COSTA, R.M., CHIGANÇAS, V., GALHARDO, R., CARVALHO, H. and MENCK, C.F., 2003. The eukaryotic nucleotide excision repair pathway. Biochimie, vol. 85, no. 11, pp. 1083-1099. http://dx.doi. org/10.1016/j.biochi.2003.10.017. PMid:14726015.

DAI, Z., WANG, S., ZHANG, W. and YANG, Y., 2017. Elevated Expression of RPA3 is involved in gastric cancer Tumorigenesis and associated with poor patient survival. Digestive Diseases and Sciences, vol. 62, no. 9, pp. 2369-2375. http://dx.doi.org/10.1007/ s10620-017-4696-6. PMid:28766245.

DAROCHA, W.D., SILVA, R.A., BARTHOLOMEU, D.C., PIRES, S.F., FREITAS, J.M., MACEDO, A.M., VAZQUEZ, M.P., LEVIN, M.J. and TEIXEIRA, S.M., 2004. Expression of exogenous genes in Trypanosoma cruzi: improving vectors and electroporation protocols. Parasitology Research, vol. 92, no. 2, pp. 113-120. http://dx.doi.org/10.1007/s00436-003-1004-5. PMid:14634799.

D'ERRICO, M., PARLANTI, E., TESON, M., DEGAN, P., LEMMA, T., CALCAGNILE, A., IAVARONE, I., JARUGA, P., ROPOLO, M., PEDRINI, A.M., ORIOLI, D., FROSINA, G., ZAMBRUNO, G., DIZDAROGLU, M., STEFANINI, M. and DOGLIOTTI, E., 2007. The role of CSA in the response to oxidative DNA damage in human cells. Oncogene, vol. 26, no. 30, pp. 4336-4343. http://dx.doi.org/10.1038/ sj.onc.1210232. PMid:17297471.

DE CASTRO, E., SIGRIST, C.J., GATTIKER, A., BULLIARD, V., LANGENDIJK-GENEVAUX, P.S., GASTEIGER, E., BAIROCH, A. and HULO, N., 2006. ScanProsite: detection of PROSITE signature matches and ProRule-associated functional and structural residues in proteins. Nucleic Acids Research, vol. 34, pp. 362365. http://dx.doi.org/10.1093/nar/gkl124. PMid:16845026.

DESQUESNES, M., HOLZMULLER, P., LAI, D.H., DARGANTES, A., LUN, Z.R. and JITTAPLAPONG, S., 2013. Trypanosoma evansi and surra: a review and perspectives on origin, history, distribution, taxonomy, morphology, hosts, and pathogenic effects. BioMed Research International, vol. 2013, no. 194176, pp. 1-22. https:// doi.org/10.1155/2013/194176.

DUTRA, A.S., STAUFFERT, D., BIANCHI, T.F., RIBEIRO, D.R.P. and VILLELA, M.M., 2021. Seroprevalence of Chagas disease in Southern Brazilian cardiac patients and their knowledge about the parasitosis and vectors. Brazilian Journal of Biology = Revista Brasleira de Biologia, vol. 81, no. 4, pp. 867-871. https://doi. org/10.1590/1519-6984.227465

GRAB, D.J. and BWAYO, J.J., 1982. Isopycnic isolation of African trypanosomes on Percoll gradients formed in situ. Acta Tropica, vol. 39, no. 4, pp. 363-366. PMid:6131595.

GENOIS, M.M., PAQUET, E.R., LAFFITTE, M.C., MAITY, R., RODRIGUES, A., OUELLETTE, M. and MASSON, J.Y., 2014. DNA repair pathways in trypanosomatids: from DNA repair to drug resistance. Microbiology and molecular biology reviews. Microbiology and Molecular Biology Reviews, vol. 78, no., 1, pp. 40-73. http://dx.doi. org/10.1128/MMBR.00045-13. PMid:24600040.
GREBER, B.J., TOSO, D.B., FANG, J. and NOGALES, E., 2019. The complete structure of the human TFIIH core complex. eLife, vol. 8, pp. e44771. http://dx.doi.org/10.7554/eLife.44771. PMid:30860024.

HAMILTON, P.B., STEVENS, J.R., GAUNT, M.W., GIDLEY, J. and GIBSON, W.C., 2004. Trypanosomes are monophyletic: evidence from genes for glyceraldehyde phosphate dehydrogenase and small subunit ribosomal RNA. International Journal for Parasitology, vol. 34, no. 12, pp. 1393-1404. http://dx.doi.org/10.1016/j. ijpara.2004.08.011. PMid:15542100.

HANAWALT, P.C. and SPIVAK, G., 2008. Transcription-coupled DNA repair: two decades of progress and surprises. Nature Reviews. Molecular Cell Biology, vol. 9, no. 12, pp. 958-970. http://dx.doi. org/10.1038/nrm2549. PMid:19023283.

HULO, N., BAIROCH, A., BULLIARD, V., CERUTTI, L., DE CASTRO, E., LANGENDIJK-GENEVAUX, P.S., PAGNI, M. and SIGRIST, C.J., 2006. The PROSITE database. Nucleic Acids Research, vol. 34, pp. 227 230. http://dx.doi.org/10.1093/nar/gkj063. PMid:16381852.

KANG, T.H., LINDSEY-BOLTZ, L.A., REARDON, J.T. and SANCAR, A., 2010. Circadian control of XPA and excision repair of cisplatinDNA damage by cryptochrome and HERC2 ubiquitin ligase. Proceedings of the National Academy of Sciences of the United States of America, vol. 107, no. 11, pp. 4890-4895. http://dx.doi. org/10.1073/pnas.0915085107. PMid:20304803.

KELLEY, L.A., MEZULIS, S., YATES, C.M., WASS, M.N. and STERNBERG, M.J., 2015. The Phyre2 web portal for protein modeling, prediction and analysis. Nature Protocols, vol. 10, no. 6, pp. 845858. http://dx.doi.org/10.1038/nprot.2015.053. PMid:25950237.

KEMP, M. and HU, J., 2017. PostExcision Events in Human Nucleotide Excision Repair. Photochemistry and Photobiology, vol. 93, no. 1, pp. 178-191. http://dx.doi.org/10.1111/php.12641. PMid:27645806.

KOHUTOVA, A., RAŠKA, J., KRUTA, M., SENEKLOVA, M., BARTA, T., FOJTIK, P., JURAKOVA, T., WALTER, C.A., HAMPL, A., DVORAK, P. and ROTREKL, V., 2019. Ligase 3-mediated end-joining maintains genome stability of human embryonic stem cells. The FASEB Journal, vol. 33, no. 6, pp. 6778-6788. http://dx.doi. org/10.1096/fj.201801877RR. PMid:30807703.

KRASIKOVA, Y.S., RECHKUNOVA, N.I., MALTSEVA, E.A., PESTRYAKOV, P.E., PETRUSEVA, I.O., SUGASAWA, K., CHEN, X., MIN, J.H. and LAVRIK, O.I., 2013. Comparative analysis of interaction of human and yeast DNA damage recognition complexes with damaged DNA in nucleotide excision repair. The Journal of Biological Chemistry, vol. 288, no. 15, pp. 10936-10947. http://dx.doi. org/10.1074/jbc.M112.444026. PMid:23443653.

LANHAM, S.M. and GODFREY, D.G., 1970. Isolation of salivarian trypanosomes from man and other mammals using DEAEcellulose. Experimental Parasitology, vol. 28, no. 3, pp. 521-534. http://dx.doi.org/10.1016/0014-4894(70)90120-7. PMid:4993889.

LETUNIC, I., KHEDKAR, S. and BORK, P., 2021. SMART: recent updates, new developments and status in 2020. Nucleic Acids Research, vol. 49, no. 1, pp. 458-460. http://dx.doi.org/10.1093/ nar/gkaa937. PMid:33104802.

LUBIN, A., ZHANG, L., CHEN, H., WHITE, V.M. and GONG, F., 2013. A human XPC protein interactome--a resource. International Journal of Molecular Sciences, vol. 15, no. 1, pp. 141-158. http:// dx.doi.org/10.3390/ijms15010141. PMid:24366067.

MACHADO, C.R., VIEIRA-DA-ROCHA, J.P., MENDES, I.C., RAJÃO, M.A., MARCELLO, L., BITAR, M., DRUMMOND, M.G., GRYNBERG, P., OLIVEIRA, D.A., MARQUES, C., VAN HOUTEN, B. and MCCULLOCH, R., 2014. Nucleotide excision repair in Trypanosoma brucei: specialization of transcription-coupled repair due to multigenic 
transcription. Molecular Microbiology, vol. 92, no. 4, pp. 756776. http://dx.doi.org/10.1111/mmi.12589. PMid:24661334.

MANANDHAR, M., LOWERY, M.G., BOULWARE, K.S., LIN, K.H., LU, Y. and WOOD, R.D., 2017. Transcriptional consequences of XPA disruption in human cell lines. DNA Repair, vol. 57, pp. 76-90. http://dx.doi.org/10.1016/j.dnarep.2017.06.028. PMid:28704716.

MASTERS, J.R. and KÖBERLE, B., 2003. Curing metastatic cancer: lessons from testicular germ-cell tumours. Nature Reviews. Cancer, vol. 3, no. 7, pp. 517-525. http://dx.doi.org/10.1038/ nrc1120. PMid:12835671.

MESSAOUD, O., REKAYA, M.B., OURAGINI, H., BENFADHEL, S., AZAIEZ, H., KEFI, R., GOUIDER-KHOUJA, N., MOKHTAR, I., AMOURI, A., BOUBAKER, M.S., ZGHAL, M. and ABDELHAK, S., 2012. Severe phenotypes in two Tunisian families with novel XPA mutations: evidence for a correlation between mutation location and disease severity. Archives of Dermatological Research, vol. 304, no. 2, pp. 171-176. http://dx.doi.org/10.1007/s00403-011-11904. PMid:22081045.

MIN, J.H. and PAVLETICH, N.P., 2007. Recognition of DNA damage by the Rad 4 nucleotide excision repair protein. Nature, vol. 449, no. 7162, pp. 570-575. http://dx.doi.org/10.1038/nature06155. PMid: 17882165.

MISTRY, J., CHUGURANSKY, S., WILLIAMS, L., QURESHI, M., SALAZAR, G.A., SONNHAMMER, E., TOSATTO, S., PALADIN, L., RAJ, S., RICHARDSON, L.J., FINN, R.D. and BATEMAN, A., 2021. Pfam: the protein families database in 2021. Nucleic Acids Research, vol. 49, no. 1, pp. 412-419. http://dx.doi.org/10.1093/nar/gkaa913. PMid:33125078.

MORETTI, N.S., MORTARA, R.A. and SCHENKMAN, S., 2020. Trypanosoma cruzi. Trends in Parasitology, vol. 36, no. 4, pp. 404405. http://dx.doi.org/10.1016/j.pt.2019.10.002. PMid:31708398.

MULLIS, K., FALOONA, F., SCHARF, S., SAIKI, R., HORN, G. and ERLICH, H., 1986. Specific enzymatic amplification of DNA in vitro: the polymerase chain reaction. Cold Spring Harbor Symposia on Quantitative Biology, vol. 51, no. 1, pp. 263-273. http://dx.doi. org/10.1101/SQB.1986.051.01.032. PMid:3472723.

NCBI RESOURCE COORDINATORS, 2018. Database resources of the National Center for Biotechnology Information. Nucleic Acids Research, vol. 46, no. 1, pp. 8-13. http://dx.doi.org/10.1093/nar/ gkx1095. PMid:29140470.

NEMZOW, L., LUBIN, A., ZHANG, L. and GONG, F., 2015. XPC: going where no DNA damage sensor has gone before. DNA Repair, vol. 36, pp. 19-27. http://dx.doi.org/10.1016/j.dnarep.2015.09.004. PMid:26422135.

OKUDA, M., KINOSHITA, M., KAKUMU, E., SUGASAWA, K. and NISHIMURA, Y., 2015. Structural Insight into the Mechanism of TFIIH Recognition by the Acidic String of the Nucleotide Excision Repair Factor XPC. Structure, vol. 23, no. 10, pp. 18271837. https://doi.org/10.1016/j.str.2015.07.009.

PASSOS-SILVA, D.G., RAJÃO, M.A., NASCIMENTO DE AGUIAR, P.H., VIEIRA-DA-ROCHA, J.P., MACHADO, C.R. and FURTADO, C., 2010. Overview of DNA Repair in Trypanosoma cruzi, Trypanosoma brucei, and Leishmania major. Journal of Nucleic Acids, vol. 2010, no. 840768, pp. 840768. http://dx.doi.org/10.4061/2010/840768. PMid:20976268.

RECK, C., MENIN, Á., PISETTA, N.L., BATISTA, F. and MILETTI, L.C., 2020. First outbreak of autochthonous "surra" in horses in Santa Catarina State, Brazil: Parasitological, hematological and biochemical characteristics. Veterinary Parasitology. Regional
Studies and Reports, vol. 21, no. 100427, pp. 100427. http://dx.doi. org/10.1016/j.vprsr.2020.100427. PMid:32862919.

SANCAR, A., LINDSEY-BOLTZ, L.A., UNSAL-KAÇMAZ, K. and LINN, S., 2004. Molecular mechanisms of mammalian DNA repair and the DNA damage checkpoints. Annual Review of Biochemistry, vol. 73, no. 1, pp. 39-85. http://dx.doi.org/10.1146/annurev. biochem.73.011303.073723. PMid:15189136.

SETIAWAN, A., NURCAHYO, W., PRIYOWIDODO, D., BUDIATI, R.T. and SUSANTI, D., 2021. Genetic and parasitological identification of Trypanosoma evansi infecting cattle in South Sulawesi, Indonesia. Veterinary World, vol. 14, no. 1, pp. 113-119. http:// dx.doi.org/10.14202/vetworld.2021.113-119. PMid:33642794.

SIEVERS, F., WILM, A., DINEEN, D., GIBSON, T.J., KARPLUS, K., LI, W., LOPEZ, R., MCWILLIAM, H., REMMERT, M., SÖDING, J., THOMPSON, J.D. and HIGGINS, D.G., 2011. Fast, scalable generation of high-quality protein multiple sequence alignments using Clustal Omega. Molecular Systems Biology, vol. 7, no. 539, pp. 1-6. http://dx.doi.org/10.1038/msb.2011.75. PMid:21988835.

SCHÄRER, O.D., 2013. Nucleotide excision repair in eukaryotes. Cold Spring Harbor Perspectives in Biology, vol. 5, no. 10, pp. 1-18. http://dx.doi.org/10.1101/cshperspect.a012609. PMid:24086042.

STARESINCIC, L., FAGBEMI, A.F., ENZLIN, J.H., GOURDIN, A.M., WIJGERS, N., DUNAND-SAUTHIER, I., GIGLIA-MARI, G., CLARKSON, S.G., VERMEULEN, W. and SCHÄRER, O.D., 2009. Coordination of dual incision and repair synthesis in human nucleotide excision repair. The EMBO Journal, vol. 28, no. 8, pp. 1111-1120. http://dx.doi.org/10.1038/emboj.2009.49. PMid:19279666.

VESSONI, A.T., GUERRA, C., KAJITANI, G.S., NASCIMENTO, L. and GARCIA, C., 2020. Cockayne Syndrome: the many challenges and approaches to understand a multifaceted disease. Genetics and molecular biology, vol. 43. Suppl. 1, pp. e20190085. http://dx.doi. org/10.1590/1678-4685-GMB-2019-0085. PMid:32453336.

WABALE, V., NALAGE, P., JOSHI, A., BHARADWAJ, R., DESHPANDE, K. and CHOWDHARY, A., 2015. Human Asian Trypanosomiasis due to Trypanosoma evansi: a rare case. The Journal of Advances in Parasitology, vol. 2, no. 3, pp. 65-68. http://dx.doi.org/10.14737/ journal.jap/2015/2.3.65.68.

YOKOI, M., MASUTANI, C., MAEKAWA, T., SUGASAWA, K., OHKUMA, Y. and HANAOKA, F., 2000. The xeroderma pigmentosum group $C$ protein complex XPC-HR23B plays an important role in the recruitment of transcription factor IIH to damaged DNA. The Journal of Biological Chemistry, vol. 275, no. 13, pp. 9870-9875. http://dx.doi.org/10.1074/jbc.275.13.9870. PMid:10734143.

YOON, T., CHAKRABORTTY, A., FRANKS, R., VALLI, T., KIYOKAWA, H. and RAYCHAUDHURI, P., 2005. Tumor-prone phenotype of the DDB2-deficient mice. Oncogene, vol. 24, no. 3, pp. 469-478. http://dx.doi.org/10.1038/sj.onc.1208211. PMid:15558025.

WORLD HEALTH ORGANIZATION - WHO. 2020 [viewed 12 March 2021]. Chagas disease (also known as American trypanonomiasis) [online]. Available from: https://www.who.int/health-topics/ chagas-disease\#tab=tab_1.

ZHENG, L., JIANG, N., SANG, X., ZHANG, N., ZHANG, K., CHEN, H., YANG, N., FENG, Y., CHEN, R., SUO, X. and CHEN, Q., 2019. In-depth analysis of the genome of Trypanosoma evansi, an etiologic agent of surra. Science China. Life Sciences, vol. 62, no. 3, pp. 406-419. http://dx.doi.org/10.1007/s11427-018-9473-8. PMid:30685829. 


\section{Supplementary Material}

Supplementary material accompanies this paper.

Figure S1 (a) Sanger sequencing electropherogram of recombinant plasmid pGEM-T-Easy::TevXPC. For this result, one vector specific primer (T7 promoter) was used. (b) BLAST result showing that the TevXPC gene inserted in pGEM-T-Easy vector is $100 \%$ identical to the database TevXPC sequence. In this illustration, only a portion of the alignment is shown. This result was obtained by joining the sequencings performed with two primers that annealing to PGEM ${ }^{\circledR}-\mathrm{T}$ Easy and three gene specific primers.

Figure S2 (a) Sanger sequencing electropherogram of recombinant plasmid pROCK::TevXPC. For this result, the TevXPC Int. primer was used. (b) BLAST result of the sequencing obtained with plasmid pROCK::TevXPC and TevXPC Int primer.

This material is available as part of the online article from http://www.scielo.br/bjb 